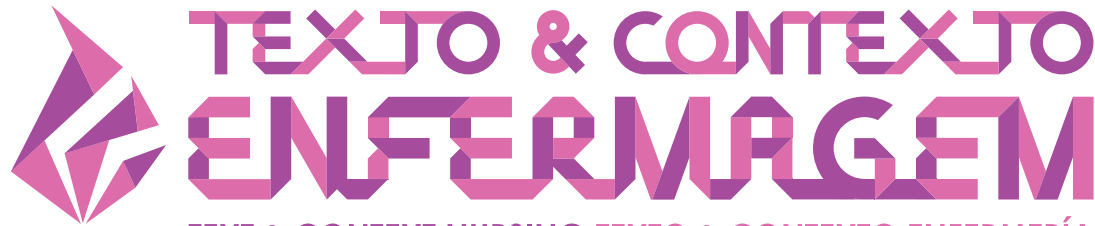

TEXT \& CONTEXT NURSING TEXTO \& CONTEXTO ENFERMERÍA

\section{PREVALENCE AND FACTORS \\ ASSOCIATED WITH NONSPECIFIC LOW BACK PAIN IN NURSING WORKERS}

\author{
Zulamar Aguiar Cargnin ${ }^{1}$ (b) \\ Dulcinéia Ghizoni Schneider ${ }^{1}$ (1) \\ lone Jayce Ceola Schneider ${ }^{2}$ (D)
}

\begin{abstract}
'Universidade Federal de Santa Catarina, Programa de Pós-graduação em Enfermagem. Florianópolis, Santa Catarina, Brasil. ${ }^{2}$ Universidade Federal de Santa Catarina, Programa de Pós-graduação em Ciências da Reabilitação. Araranguá, Santa Catarina, Brasil.
\end{abstract}

\begin{abstract}
Objective: to determine the prevalence and factors associated with nonspecific low back pain in nursing workers in a public hospital in the South of the country.

Method: a cross-sectional study involving 301 nursing workers. Data collection was carried out from May to October 2017 and, in addition to a questionnaire with sociodemographic, work, health conditions, lifestyle and psychosocial conditions, the Nordic Musculoskeletal Questionnaire was used as a screening tool for low back pain and the Self Report Questionnaire to assess the possibility of minor psychiatric disorders. The Chi-Square test was used to analyze the association between variables, and multivariate analysis with Binary Logistic Regression to estimate the Odds Ratio and the $95 \%$ confidence intervals.

Results: the prevalence of nonspecific low back pain was $51.4 \%(95 \% \mathrm{Cl}: 45.5-57.3)$ in the last 12 months and $45.4 \%$ (95\% Cl: $39.4-51.3)$ in the last seven days, and limitation for activities of daily living and work of $18.1 \%$ (95\% Cl: 13.5-22.7). The presence of other diseases and psychosocial and psychological factors increased the chances of presenting or low back pain discomfort.

Conclusion: the results demonstrate the need for greater attention to nursing workers, mainly related to the presence of musculoskeletal pain and to their mental suffering.
\end{abstract}

DESCRIPTORS: Low back pain. Nursing. Prevalence. Risk factors. Professional diseases. 


\section{PREVALÊNCIA E FATORES ASSOCIADOS À LOMBALGIA INESPECÍFICA EM TRABALHADORES DE ENFERMAGEM}

\section{RESUMO}

Objetivo: determinar a prevalência e fatores associados à dor lombar inespecífica em trabalhadores de enfermagem em um hospital público do sul do país.

Método: estudo transversal envolvendo 301 trabalhadores de enfermagem. A coleta de dados foi realizada no período de maio a outubro de 2017 e foram aplicados, além de um questionário com dados sociodemográficos, laborais, condições de saúde, estilo de vida e condições psicossociais, o Nordic Musculoskeletal Questionnaire como instrumento de rastreio para dor lombar e o Self Report Questionnaire para avaliação da possibilidade de distúrbios psíquicos menores. Utilizou-se o teste Qui-Quadrado para analisar a associação entre as variáveis e análise multivariável com Regressão Logística Binária para estimar o Odds Ratio e os intervalos de confiança de $95 \%$.

Resultados: a prevalência de dor lombar inespecífica foi de 51,4\% (IC95\%: 45,5-57,3) nos últimos 12 meses e 45,4\% (IC95\%: 39,4-51,3) nos últimos sete dias e limitação para atividades de vida diária e de trabalho de 18,1\% (IC95\%: 13,5-22,7). A presença de outras doenças e fatores psicossociais e psicológicos aumentaram as chances de apresentar dor ou desconforto lombar.

Conclusão: os resultados demonstram a necessidade de maior atenção aos trabalhadores de enfermagem, principalmente relacionada à presença de dores musculoesqueléticas e ao seu sofrimento mental.

DESCRITORES: Dor lombar. Enfermagem. Prevalência. Fatores de risco. Doenças profissionais.

\section{PREVALENCIA Y FACTORES ASOCIADOS A LA LUMBALGIA NO ESPECÍFICA EN TRABAJADORES DE ENFERMERÍA}

\section{RESUMEN}

Objetivo: determinar la prevalencia y los factores asociados a la lumbalgia no específica en trabajadores de Enfermería de un hospital público del sur del país.

Método: estudio transversal en el que participaron 301 trabajadores de Enfermería. La recolección de datos se realizó entre mayo y octubre de 2017 y, además de un cuestionario con datos sociodemográficos, laborales, afecciones de salud, estilo de vida y condiciones psicosociales, se aplicó el Nordic Musculoskeletal Questionnaire como instrumento de rastreo para la lumbalgia y el Self Report Questionnaire para evaluar la posibilidad de trastornos psíquicos menores. Se utilizó la prueba de Chi-Cuadrado para analizar la asociación entre las variables y análisis multivariado con Regresión Logística Binaria para estimar el Odds Ratio y los intervalos de confianza del $95 \%$.

Resultados: la prevalencia de la lumbalgia no específica fue del 51,4\% (IC95\%: 45,5-57,3) en los últimos 12 meses y del 45,4\% (IC95\%: 39,4-51,3) en los últimos siete días, además de limitación en actividades de la vida diaria e de trabajo del 18,1\% (IC95\%: 13,5-22,7). La presencia de otras enfermedades y de otros factores psicosociales y psicológicos aumentaron las probabilidades de presentar dolor o malestar lumbar.

Conclusión: los resultados demuestran que es necesario prestar mayor atención a los trabajadores de Enfermería, principalmente en relación con la presencia de dolores musculoesqueléticos y con el sufrimiento mental.

DESCRIPTORES: Lumbalgia. Enfermería. Prevalencia. Factores de riesgo. Enfermedades profesionales. 


\section{INTRODUCTION}

Work-related illnesses have increased as a result of the change in the epidemiological profile of illness among workers and of the changes in the world of work. These changes lead to precarious working conditions with illnesses that affect workers' safety and health. Problems related to musculoskeletal pain that manifest with different degrees of functional disability have been highlighted. ${ }^{1-2}$

Lumbar pain or Low Back Pain (LBP) is a musculoskeletal condition of moderate or severe pain in the lower region of the lumbar spine that has a prevalence of about $60 \%$ to $80 \%$ in the population at some point in life. It is a global public health problem because it affects all age groups and socioeconomic levels, involving prevention, promotion, education and not only health rehabilitation actions. It is multifactorial, comprises sociodemographic, occupational and psychosocial factors, health status, lifestyle or behavior. Approximately $80 \%$ of the cases are nonspecific, that is, they do not have a specific and well-determined diagnosis. ${ }^{3-5}$

Estimates from the Global Burden of Disease (GBD) Study on the incidence of diseases in 188 countries, between 1990 and 2013, identified low back pain as the main factor that causes years of living with disability, along with depressive disorders. Low back pain was among the ten health problems in all countries analyzed, and treatment costs are high. ${ }^{6}$

It is very common in nursing professionals who have a different profile from the general population and are exposed to many workloads inherent to their activities, with physical and emotional repercussions. ${ }^{7-9}$ The occurrence of low back pain and other musculoskeletal disorders contribute to absenteeism, job loss and decreased quality of life. ${ }^{7}$ Monitoring worker health can mean the reduction of occupational diseases. ${ }^{10}$

Given the above, this research aims to determine the prevalence and factors associated with nonspecific low back pain in nursing workers in a public hospital in the South of the country.

\section{METHOD}

This is a cross-sectional study, part of the master's thesis entitled "Nursing work process and its influence on nonspecific low back pain". It was carried out in a medium- and high-complexity public general hospital in the South of Brazil, a reference center in various specialties, including care for clinical, surgical, orthopedic and neurological patients with nearly 225 beds and a staff of approximately 1,200 employees.

The study population consisted of 301 nursing professionals, including assistants, technicians and nurses of both genders. The inclusion criteria were working exclusively in Nursing and exercising their activities for at least one year. The exclusion criteria were low back pain with specific causes such as spondylolisthesis, herniated disc, spinal canal stenosis, infectious spine diseases, spinal tumors and fractures. Data was collected between May and October 2017.

The instruments used were self-applied and consisted in a form, developed by the researchers, with sociodemographic data (gender, age, weight, height, Body Mass Index-BMI, marital status, number of children), health conditions (current health problem, depression, stress, hypertension, diabetes, low back pain, gastrointestinal problems, cardiovascular problems, lung disease, hypothyroidism, rheumatic disease, orthopedic disease), work factors (job title, shift, work schedule, shift hours, other employment, years of work, wanting to change sectors, wanting to change professions, accidents at work), life habits (smoking, use of alcohol, physical activity, leisure activities), psychosocial factors (job satisfaction, feeling at the end of the journey, neuropsychic symptoms, perspectives within the institution, recognition at work, professional achievement, professional development); and in the Nordic Musculoskeletal Questionnaire (NMQ) and Self Report Questionnaire (SRQ-20). 
Pain intensity was measured using the Visual Numerical Scale (VNS), a 10-point numerical scale where 0 is no pain and 10 means the worst pain. It was categorized as mild pain (1 to 2), moderate pain (3 to 7) and severe pain (8 to 10). The NMQ useful to estimate the prevalence of musculoskeletal pain or discomfort in the lumbar region (dependent variable), the limitation in carrying out activities in the last twelve months, and the prevalence of pain in the last seven days in the anatomical areas shown by a figure. The Brazilian version has been validated ${ }^{11}$ and has good reliability.

The SRQ-20 assessed the possibility of Minor Psychiatric Disorders (MPDs). It was developed by the World Health Organization (WHO), translated and validated in Brazil, ${ }^{12}$ with a sensitivity of $83 \%$ and a specificity of $80 \%$, and can be used in the working population. It is a self-administered, multidimensional instrument with 20 yes/no questions, divided into four groups of symptoms: depressiveanxious mood, somatic symptoms, decreased vital energy, and depressed thoughts. It is easy to understand, quick to apply, low cost and internationally standardized. The cutoff point used was 6/7 for women ${ }^{13}$ and $5 / 6$ for men. ${ }^{12}$

The database was inserted into the Excel program. After being reviewed, it was transferred to the Statistical Package for Social Sciences (SPSS), version 23, where the data were processed and analyzed. The variables were analyzed in a descriptive manner: the categorical ones, by absolute and relative frequencies, and the continuous ones, by means and standard deviation, followed by bivariate analyses using the Chi-Square test $\left(X^{2}\right)$. Binary logistic regression was used to estimate the Odds Ratio (OR) and the $95 \%$ confidence intervals $(95 \% \mathrm{Cl})$ in the gross and adjusted analysis. For the selection of possible confounding variables, the criterion of $p<0.10$ was adopted for entry into the adjusted analysis. The confounding factors considered were adjusted for age group, gender, marital status, BMI, job title, shift, years of work, hypertension, diabetes, depression, stress, cardiovascular disease, lung disease, hypothyroidism, rheumatic disease, and orthopedic disease.

The research project was conducted in accordance with the required ethical standards.

\section{RESULTS}

All the nursing workers were invited to participate, resulting in a census with 353 workers who, after applying the inclusion and exclusion criteria, were summarized in a sample of 301 professionals (87.8\%).

Regarding the sociodemographic characteristics (Table 1), there was predominance of females (83.4\%); of professionals who are married or live with a partner $(66.9 \%)$; and of those who have children $(69.2 \%)$. The mean age was 41.12 years old (SD 8.94) with a minimum of 22 and a maximum of 64 (median of 40 years old). The mean BMI was $26.35 \mathrm{~kg} / \mathrm{m}^{2}$ (SD 4.54 ), with a minimum of $17.97 \mathrm{~kg} / \mathrm{m}^{2}$ and a maximum of $46.71 \mathrm{~kg} / \mathrm{m}^{2}$.

As for the group of variables related to lifestyle and health conditions (Table 2), nearly one disease per person was reported. Analyzing only workers with nonspecific low back pain, $69.9 \%$ reported having health problems, the most common being self-reported low back pain, with $44.1 \%$, and stress, with $28.7 \%$. 
Table 1 - Sociodemographic characteristics of the Nursing workers of a public hospital, Florianópolis, SC, Brazil, 2017. ( $n=301)$

\begin{tabular}{|c|c|c|}
\hline Variables & $\mathbf{n}$ & $\%$ \\
\hline \multicolumn{3}{|l|}{ Gender $(n=301)$} \\
\hline Male & 50 & 16.6 \\
\hline Female & 251 & 83.4 \\
\hline \multicolumn{3}{|l|}{ Age $(n=295)$} \\
\hline 30 years old or less & 35 & 11.9 \\
\hline $31-40$ years old & 117 & 39.7 \\
\hline 41 to 50 years old & 88 & 29.8 \\
\hline 51 years old or more & 55 & 18.6 \\
\hline \multicolumn{3}{|l|}{ Marital status ( $n=299)$} \\
\hline Single & 68 & 22.7 \\
\hline Married/Living with partner & 200 & 66.9 \\
\hline Separated/Divorced & 26 & 8.7 \\
\hline Widow/Widower & 5 & 1.7 \\
\hline \multicolumn{3}{|l|}{$\mathrm{BMI}^{*}(\mathrm{n}=288)$} \\
\hline Normal & 127 & 44.6 \\
\hline Overweight & 104 & 36.5 \\
\hline Obesity & 54 & 18.9 \\
\hline \multicolumn{3}{|l|}{ Number of children $(n=296)$} \\
\hline No children & 91 & 30.7 \\
\hline 1 child & 91 & 30.7 \\
\hline 2 children & 80 & 27.0 \\
\hline More than 2 children & 34 & 11.5 \\
\hline
\end{tabular}

*BMI: Body Mass Index

The prevalence of pain or discomfort in the lower back in the last 12 months was $51.4 \%$ (95\% Cl: $45.5-57.3)$, and $45.4 \%$ in the last week (95\% Cl: $39.4-51.3)$. Nonspecific low back pain was prevalent in relation to other regions of the body and was followed by the cervical region (40.9\%), shoulders (46.1\%) and hips (39.7\%) in the last 12 months; and the cervical region (40.3\%), the hip $(33.3 \%)$ and shoulders $(34.7 \%)$ in the last week. Approximately $85 \%$ of professionals reported having at least one musculoskeletal symptom. As for the limitation in Activities of Daily Living (ADLs) due to its musculoskeletal symptom in the lumbar region in the last 12 months, it was $18.1 \%(95 \% \mathrm{Cl}$ : 13.5-22.7).

The mean intensity of low back pain was 5.6 (SD 2.65) and represents moderate intensity. Intensity was higher among technicians and assistants (5.92) in relation to nurses (4.88) and showed no difference between men and women. 
Table 2 - Health conditions and lifestyle of the Nursing workers of a public hospital, Florianópolis, SC, Brazil, 2017. $(n=301)$

\begin{tabular}{|c|c|c|}
\hline Lifestyle and health variables & $\mathbf{n}$ & $\%$ \\
\hline Current health problems $(n=299)$ & 172 & 42.5 \\
\hline Arterial hypertension & 29 & 9.7 \\
\hline Diabetes Mellitus & 15 & 5.0 \\
\hline Depression & 22 & 7.4 \\
\hline Stress & 57 & 19.1 \\
\hline Low back pain & 75 & 25.1 \\
\hline Thyroid dysfunction & 32 & 10.7 \\
\hline Orthopedic & 27 & 9.0 \\
\hline Obesity & 4 & 1.3 \\
\hline Others & 40 & 13.4 \\
\hline \multicolumn{3}{|l|}{ Work accidents $(n=294)$} \\
\hline Yes & 141 & 48.0 \\
\hline No & 153 & 52.0 \\
\hline \multicolumn{3}{|l|}{ Smoking $(n=298)$} \\
\hline Yes & 26 & 8.7 \\
\hline No & 272 & 91.3 \\
\hline \multicolumn{3}{|l|}{ Alcohol consumption $(n=298)$} \\
\hline Socially & 135 & 45.3 \\
\hline Weekends & 38 & 12.8 \\
\hline Sometimes & 62 & 20.8 \\
\hline Daily & 0 & 0 \\
\hline Never & 63 & 21.1 \\
\hline \multicolumn{3}{|l|}{ Physical activity $(n=294)$} \\
\hline 1 time a week & 34 & 11.5 \\
\hline 2 times a week & 57 & 19.3 \\
\hline 3 times a week & 57 & 19.3 \\
\hline 4-7 times a week & 19 & 6.4 \\
\hline Does not practice & 128 & 43.4 \\
\hline \multicolumn{3}{|l|}{ Leisure $(n=295)$} \\
\hline Yes & 267 & 90.5 \\
\hline No & 28 & 9.5 \\
\hline
\end{tabular}

The work characteristics of the participants are presented in Table 3.

The prevalence of suspected common psychiatric disorder, measured by the SQR-20 questionnaire, was $31.5 \%$. The prevalence of MPDs among nurses was $24.1 \%$ and among technicians/ assistants, $33.6 \%$. There was practically no difference in prevalence between the gender: male (34\%) and female (31\%). The mean of positive answers was 4.97 (SD 4.02), with a minimum of 0 and a maximum of 17 positive answers. The group of symptoms with the highest prevalence with low back pain focused on somatic symptoms and depressive-anxious mood. 
Table 3 - Work characteristics of the Nursing workers of a public hospital, Florianópolis, SC, Brazil, 2017. $(n=301)$

\begin{tabular}{lcc}
\hline Work variables & $\mathbf{n}$ & \% \\
\hline Professional category $(\mathrm{n}=300)$ & & \\
$\quad$ Assistant/Technician & 239 & 79.7 \\
$\quad$ Nurse & 61 & 20.3 \\
Working time in the institution $(\mathrm{n}=280)$ & & \\
$\quad$ Up to 4 years & 110 & 39.3 \\
$\quad$ More than 4 to 8 years & 31 & 11.1 \\
$\quad$ More than 8 to 14 years & 81 & 28.9 \\
$\quad$ More than 14 years & 58 & 20.7 \\
Shift ( $\mathrm{n}=300)$ & & \\
$\quad$ Day & 182 & 60.7 \\
$\quad$ Night & 118 & 39.3 \\
Overtime in the institution $(\mathrm{n}=300)$ & & \\
$\quad$ Yes & 230 & 76.7 \\
$\quad$ No & 70 & 23.3 \\
Other employment link $(\mathrm{n}=300)$ & & \\
$\quad$ Yes & 83 & 27.7 \\
$\quad$ No & 217 & 72.3 \\
Work regime ( $\mathrm{n}=299)$ & & \\
6 hours & 53 & 17.7 \\
8 hours & 10 & 3.3 \\
12 hours & 236 & 78.9 \\
\hline
\end{tabular}

In the bivariate analyses, some associations were found related to health problems and professional variables (Table 4). However, in the analysis adjusted for confounding factors, it remained associated only with a current health problem that increased 2.43 times the chances of presenting low back pain.

As for the group of variables that referred to feelings, satisfaction and perspectives in the work environment, there were many statistically significant associations with nonspecific low back pain (Table 5). After adjustments due to confounding factors, they remained associated with low back pain: job satisfaction, feeling of overload, moodiness and fatigue at the end of the day, the feeling of devaluation at work, neuropsychic symptoms of irritation, anxiety and insomnia. Workers with overload and fatigue resulting from work can be, respectively, $2.93(95 \% \mathrm{Cl} 1.48-5.78)$ and $3.07(95 \% \mathrm{Cl} 1.44-$ 6.56) times more likely to experience low back pain or discomfort. Being in a bad mood at the end of the day can increase $5.3(95 \% \mathrm{Cl} 1.67-16.78)$ times the chances of low back pain or discomfort. Greater job satisfaction was shown to be a protective factor and the chances of having low back pain decreased by $70 \%$. Symptoms of irritation and anxiety increase by $2.66(95 \% \mathrm{Cl} 1.31-5.39)$ and 1.88 $(95 \% \mathrm{Cl} 1.02-3.47)$, respectively, the chances of having low back pain. 
Table 4 - Factors associated with low back pain in Nursing workers of a public hospital, Florianópolis, SC, Brazil, 2017. $(n=301)$

\begin{tabular}{|c|c|c|c|c|c|}
\hline Variables & $\mathbf{n}$ & $\begin{array}{c}\text { Low back pain } \\
n(\%)\end{array}$ & p-value* & $\begin{array}{c}\text { Gross OR }^{\dagger} \\
(95 \% \mathrm{Cl})^{\ddagger}\end{array}$ & $\begin{array}{c}\text { Adjusted OR } \\
(95 \% \mathrm{Cl})^{\ddagger}\end{array}$ \\
\hline Professional category & & & 0.042 & & \\
\hline Assistant/Technician & 219 & $120(54.8)$ & & $1.81(1.01-3.25)$ & $1.66(0.32-1.37)$ \\
\hline Nurse & 60 & $24(40.0)$ & & 1 & 1 \\
\hline Current health problem & & & $<0.001$ & & \\
\hline No & 120 & $43(35.8)$ & & 1 & 1 \\
\hline Yes & 158 & $100(63.3)$ & & $3.08(1.88-5.05)$ & $2.43(1.38-4.28)^{\pi}$ \\
\hline Stress & & & $<0.001$ & & \\
\hline No & 223 & $102(45.7)$ & & 1 & 1 \\
\hline Yes & 55 & $41(74.5)$ & & $3.47(1.79-6.73)$ & $1.48(0.56-3.85)$ \\
\hline Wish to change sector & & & 0.012 & & \\
\hline No & 195 & $91(46.7)$ & & 1 & 1 \\
\hline Yes & 70 & $45(64.3)$ & & $2.05(1.17-3.61)$ & $2.01(0.99-4.09)$ \\
\hline Wish to change profession & & & 0.005 & & \\
\hline No & 205 & $97(47.3)$ & & 1 & 1 \\
\hline Yes & 62 & $42(67.7)$ & & $2.33(1.28-4.25)$ & $2.17(0.99-4.74)$ \\
\hline
\end{tabular}

* $p$-value: significance level $<0.05$, Chi-Square test; $†$ Gross OR: analysis of the odds ratio without confounding variables in univariate logistic regression; $\neq 95 \% \mathrm{Cl}: 95 \%$ confidence interval; §Adjusted OR: odds ratio analysis in multivariate logistic regression with confounding variables: age group, gender, marital status, BMI, job title, shift, years of work, hypertension, diabetes, depression, stress, cardiovascular disease, lung disease, hypothyroidism, rheumatic disease, orthopedic disease; IIAdjusted by age group gender, marital status, BMI, position, shift, years of work; Result of the adjusted analysis: there are significant differences between the variables studied.

The prevalence of suspected common psychiatric disorder, measured by the SQR-20 questionnaire, showed a statistically significant relationship with low back pain $(p<0.001)$. The binary logistic regression analysis, after adjustments for confounding factors, showed that the presence of suspected minor mental disorders remained significant and increased by 4.68 (95\% Cl 2.09-10.46) the chance of presenting low back pain or discomfort (Table 5). 
Table 5 - Association between nonspecific low back pain and psychosocial variables in Nursing workers of a public hospital, Florianópolis, SC, Brazil, 2017.

\begin{tabular}{|c|c|c|c|c|c|}
\hline Variables & $\mathbf{n}$ & $\begin{array}{c}\text { Low back pain } \\
n(\%)\end{array}$ & p-value* & $\begin{array}{c}\text { Gross OR }^{\dagger} \\
(95 \% \mathrm{Cl})^{\ddagger}\end{array}$ & $\begin{array}{c}\text { Adjusted OR } \\
(95 \% \mathrm{Cl})^{\ddagger}\end{array}$ \\
\hline Job satisfaction & & & $<0.001$ & & \\
\hline No & 58 & $44(75.9)$ & & 1 & 1 \\
\hline Yes & 208 & $93(44.7)$ & & $0.25(0.13-0.50)$ & $0.30(0.13-0.70)$ \\
\hline Overload (end of workday) & & & 0.001 & & \\
\hline No & 200 & $91(45.5)$ & & 1 & 1 \\
\hline Yes & 78 & $53(68.0)$ & & $2.54(1.46-4.41)$ & $2.93(1.48-5.78)$ \\
\hline Bad mood (end of workday) & & & $<0.001$ & & \\
\hline No & 248 & $119(48.0)$ & & 1 & 1 \\
\hline Yes & 30 & $25(83.3)$ & & $5.42(2.01-14.62)$ & $5.30(1.67-16.78)$ \\
\hline Fatigue (end of workday) & & & 0.002 & & \\
\hline No & 224 & $106(47.3)$ & & 1 & 1 \\
\hline Yes & 54 & $38(70.4)$ & & $2.64(1.39-5.02)$ & $3.07(1.44-6.56)$ \\
\hline Feeling valued & & & 0.003 & & \\
\hline Yes & 31 & $8(25.8)$ & & 1 & 1 \\
\hline No & 129 & $78(60.5)$ & & $4.40(1.82-10.59)$ & $4.00(1.43-11.18)$ \\
\hline More or less & 107 & $49(45.8)$ & & $2.43(0.99-5.91)$ & $1.93(0.67-5.55)$ \\
\hline Did not answer & 4 & $2(50.0)$ & & $2.87(0.34-23.92)$ & $2.25(0.16-32.59)$ \\
\hline Annoyance & & & $<0.001$ & & \\
\hline No & 184 & $82(44.6)$ & & 1 & 1 \\
\hline Yes & 81 & $56(69.1)$ & & $2.79(1.60-4.85)$ & $2.66(1.31-5.39)$ \\
\hline Anxiety & & & 0.004 & & \\
\hline No & 156 & $70(44.9)$ & & 1 & 1 \\
\hline Yes & 108 & $68(63.0)$ & & $2.09(1.26-3.45)$ & $1.88(1.02-3.47)$ \\
\hline Insomnia & & & $<0.001$ & & \\
\hline No & 198 & $90(45.5)$ & & 1 & 1 \\
\hline Yes & 66 & $48(72.7)$ & & $3.2(1.74-5.89)$ & $2.83(1.34-5.95)$ \\
\hline Suspicion of MPDs" & & & $<0.001$ & & \\
\hline No & 176 & $69(39.2)$ & & 1 & 1 \\
\hline Yes & 81 & $59(72.8)$ & & $4.15(2.33-7.39)$ & 4.68(2.09-10.46) \\
\hline
\end{tabular}

${ }^{*}$ - -value: significance level $<0.05$, Chi-Square test;

tGross OR: analysis of the odds ratio without confounding variables in univariate logistic regression; $795 \% \mathrm{Cl}$ : 95\% confidence interval;

$\S$ Adjusted OR: odds ratio analysis in multivariate logistic regression with confounding variables:

age group, gender, marital status, BMI, job title, shift, years of work, hypertension, diabetes, depression, stress, cardiovascular disease, lung disease, hypothyroidism, rheumatic disease, orthopedic disease;

IIMPDs: Minor Psychiatric Disorders. 


\section{DISCUSSION}

The prevalence of low back pain was shown to be high in the nursing team. These results demonstrate that the physical requirements at the spine level, especially the lumbar one, are representative in this health professional group. This finding corroborates other national and international research studies with nursing professionals with rates ranging from $54.3 \%$ to $85.9 \% .^{7-9,14-20}$

In relation to the other regions of the body, the one most affected was also the lumbar. The same finding was demonstrated by other studies.,15,18,21-22 The high risk of health problems in Nursing can be related to working conditions and work organization and to the type of task performed. A study that also pointed out a high prevalence listed the tasks and characteristics of real work activities as the major cause of lumbar musculoskeletal symptoms. ${ }^{22}$

In the present study, most of the respondents reported that, in the last year, low back pain did not prevent them from attending work or that they even worked in pain. This condition is presenteeism, characterized by attending work in a nonproductive manner without performing well due to work-related illnesses or injuries. ${ }^{7}$ A study verified high rates of presenteeism among nursing workers, which caused a reduction in work performance and manifested itself with presence of musculoskeletal disorders. ${ }^{7}$ Another study showed presenteeism as a predictor of low back pain at work. ${ }^{9}$

The fact of working even with pain increases the possibility of worsening the condition, decreases the quality of care provided, and predisposes to the occurrence of errors. ${ }^{7}$ So, even working in pain can have negative implications for the worker's health and for the quality of care. On the other hand, other studies have identified pain as an important cause of leave. ${ }^{15,23-25}$ Musculoskeletal disorders including low back pain in addition to absenteeism cause reduced productivity and incapacity for work. ${ }^{26}$

The presence of other diseases can be a risk factor for low back pain. ${ }^{24}$ Another study also verified an increased prevalence in individuals who had other health problems such as hypertension, arthritis/rheumatism, arthrosis, headache/migraine, insomnia and common mental disorder. ${ }^{27}$ In the present study, only stress was associated, in the bivariate analysis, with low back pain.

Psychosocial and psychological factors show very relevant data in this study. These findings indicate that they are not only mechanical aspects, but that also other factors are involved and cause pain and discomfort. Thus, factors such as job satisfaction, feeling of overload, moodiness and fatigue at the end of the day, the feeling of devaluation at work, neuropsychic symptoms of irritation, anxiety and insomnia can influence the genesis of low back pain.

Symptoms like anxiety and irritation can exacerbate painful syndromes. These symptoms can release pro-inflammatory mediators that can damage tissues and increase neural processing. When strong emotions are the result of perceived pain or threat, the body increases neural processing and the likelihood that bodily sensations are interpreted as painful and leads to the development or exacerbation of chronic low back disease. ${ }^{28}$

The feeling of fatigue and overload after a workday; as well as overload as a factor that causes job dissatisfaction were representative in this study. Feeling overwhelmed and fatigued can predispose individuals to musculoskeletal disorders. A study that found a high prevalence of musculoskeletal disorder in the last year among nursing professionals in a hospital detected greater fatigue and the need for rest, and that they were risk factors for reducing the ability to work. ${ }^{29}$ Muscles, tendons, ligaments and capsules lack rest for their recovery, and work overload (staff shortage, number and severity of patients) increases the chances of musculoskeletal disorders, fatigue and psychological symptoms. ${ }^{15}$ Work overload, imbalance between physical or psychological capacities and professional demands generate stress with personal, clinical and organizational repercussions. ${ }^{30}$ Nursing is considered to be one of the most stressful professions. ${ }^{31-32}$ The relationship between low back pain and stress is corroborated by another study that found a relationship between psychological stress 
and musculoskeletal problems, in which maintained stress levels increased the risk of developing symptoms and especially in the lumbar and cervical areas. ${ }^{32}$

In this sense, psychosocial and psychological factors can influence the chronicity and frequency of low back pain, as well as the perception and threshold of pain with increased reports of musculoskeletal pain. However, not everyone who has chronic low back pain has psychological problems, because it depends on how each person perceives and controls pain. Thus, psychological changes must be evaluated along with people's coping behavior in pain. ${ }^{33}$ Pain makes individuals less tolerant to the psychological demands of work and increases pain reporting through effects on the processing of sensory information in the system central nervous system. ${ }^{34}$ There seems to be a vicious cycle where the occurrence of low back pain and functional disability can lead to the intensification of psychological distress, worsening the mental health state ${ }^{35}$ In addition, stressors in the physical and psychosocial work environment act negatively on the ability to work. ${ }^{36}$

Self-reported insomnia also influenced low back pain. Sleep deprivation interferes with quality of life and with the ability to work. Lack of sleep can have consequences such as irritability, decreased cognitive ability and the ability to perform tasks, as well as it can lead to accidents and errors. It results in symptoms like insomnia and excessive sleepiness during the day. The probability of cardiovascular, gastrointestinal and other problems is higher. ${ }^{31}$

As for job satisfaction, this was reported by most of the workers and can work as a protective factor against low back pain. It signals that they can consider their activity a challenge, despite not entirely favorable working conditions. ${ }^{31}$

Mental disorders are an important factor for illness among workers. There are several studies with varying prevalence and population with suspected MPDs. In Nursing, there are prevalence values of $22.9 \%,{ }^{38} 32.6 \%,{ }^{13} 33.3 \%,{ }^{29}$ and $33.7 \%{ }^{37}$ among the studies. MPDs are characterized by anxious, depressive or somatic symptoms that do not meet all the criteria of mental illness and cause symptoms such as sadness, anxiety, fatigue, decreased concentration, irritability and insomnia, which can cause functional disability. ${ }^{37,39}$ They are mild psychic disorders and are not part of the international classification of diseases. ${ }^{39}$

The MPDs in the study were determined by symptoms such as insomnia, anxiety, depression, fatigue, stress, irritability and somatic complaints, and most of them are associated with low back pain. They can be related to work demands. ${ }^{40-41}$ They represent high social and economic costs, cause absenteeism, and lead to greater demand in the health services. Work factors such as dissatisfaction, stress, excessive work paces, strict controls, and environmental conditions can also compromise mental health. ${ }^{38,40}$ Health professionals are vulnerable due to the psychosocial demands they are subjected to. ${ }^{38}$ In hospital workers, mental suffering can be aggravated by living with human beings in their fragility at the time of their illness. ${ }^{39}$

Low back pain can cause mental effects in individuals, such as anxiety, irritability, insomnia and others or; conversely, the mental symptoms lead to pain. The associations found in this study should be explored in other future studies to assess the impact of low back pain and other musculoskeletal pain along with psychosocial and psychological aspects in relation to the work environment. These aspects must be identified and preventive measures must be implemented.

As for the limitations of the study, the main one refers to reverse causality, in which it is not possible to assess direct causality relationships between the variables studied because the events are analyzed simultaneously. Some data may be underestimated because they are self-reported, such as the weight and height values that generated the BMI. A positive factor was the census sense of the study, where it was possible for everyone to participate and for the evaluation of a series of variables covering sociodemographic aspects, life habits, work and work context aspects, health conditions and psychosocial aspects related to work. Despite being used worldwide, the NMQ questionnaire had 
many omissions regarding the completion of negative answers. Direct interviews with the participants are suggested to increase accuracy. It can lead to a higher frequency of estimated pain prevalence due to the standard question type of the questionnaire, which includes, in addition to pain, other symptoms such as discomfort or numbness. The results must be interpreted with caution and other studies with a longitudinal design should be sought where long-term follow-up occurs.

\section{CONCLUSION}

There was a high prevalence of low back pain mainly associated with the presence of other diseases and with psychosocial and psychological factors. This demonstrates how much the hospital environment promotes not only physical, but psychological wear out in the worker.

Nursing is predisposed to an intense psycho-emotional load and is a profession subjected to stress and other agents that cause tension, such as high work demands and overloads that contribute to the emergence of diseases. In the prevention and treatment of low back pain, a biopsychosocial approach is required that involves, in addition to the control of physical factors, the visualization, contextualization and control of psychosocial factors that influence the onset and perpetuation of pain.

The findings of this study reinforce other publications and raise discussions and reflections. Further research studies on this topic are suggested, increasing the awareness of managers and public authorities to improve working conditions and quality of life for nursing workers, minimizing the occurrence of injuries.

\section{REFERENCES}

1. Fernandes MA, Santos JDM, Moraes LMV, Lima JSR, Feitosa CDA, Sousa LFC. Mental and behavioral disorders in workers: a study on work leave. Rev Esc Enferm USP.[Internet]. 2018 [cited 2019 Mar 17];52:e03396. Available from: https://www.researchgate.net/publication/329687621_ Mental_and_behavioral_disorders_in_workers_a_study_on_work_leave

2. Shoji S, Souza NVDO, Farias SNP, Vieira LC, Progianti JM. Proposals for improving working conditions at an outpatient clinic: the nursing standpoint. Esc Anna Nery [Internet]. 2016 [cited 2018 Aug 15];20(2):303-9. Available from: http://www.scielo.br/scielo.php?pid=S1414$81452016000200303 \&$ script=sci_arttext\&tlng=en

3. Nascimento PRC, Costa LOP. Low back pain prevalence in Brazil: a systematic review. Cad Saúde Pública [Internet]. 2015 [cited 2018 Oct 25];31(6):1141-55. Available from: http://www. scielo.br/scielo.php?script=sci_arttext\&pid=S0102-311X2015000601141

4. Correia VG, Foganholi G, Macedo CSG. Análise da flexão lombar e incapacidade funcional: um estudo comparativo entre sujeitos assintomáticos e pacientes com lombalgia. Cient Cienc Biol Saude [Internet]. 2015 [cited 2018 Oct 25];17(3):194-7. Available from: http://www.pgsskroton. com.br/seer/index.php/JHealthSci/article/view/3068

5. Hartvigsen J, Hancock MJ, Kongsted A, Louw Q, Ferreira ML, Genevay S et al. What low back pain is and why we need to pay attention. Lancet [Internet]. 2018 [cited 2019 Mar 17];391(10137):235667. Available from: https://www.sciencedirect.com/science/article/pii/S014067361830480X

6. Vos, T, Barber RM, Bertozzi-Villa A, Biryukov S, Bolliger I, Charlson F et al. Global, regional, and national incidence, prevalence, and years lived with disability for 301 acute and chronic diseases and injuries in 188 countries, 1990-2013: a systematic analysis for the Global Burden of Disease Study 2013. Lancet [Internet]. 2015 [cited 2018 Oct 25];386(9995):743-800. Available from: https://www.ncbi.nlm.nih.gov/pubmed/26063472

7. Santos HEC, Marziale MHP, Felli VEA. Presenteeism and musculoskeletal symptoms among nursing professionals. Rev. Latino-Am. Enfermagem [Internet]. 2018 [cited 2019 Mar 16];26:e3006. Available from: http://www.scielo.br/scielo.php?script=sci_arttext\&pid=S0104-11692018000100308\&lng=en 
8. Suliman M. Prevalence of low back pain and associated factors among nurses in Jordan. Nurs Forum [Internet]. 2018 [cited 2019 Mar 17];53:425-31. Available from: https://onlinelibrary.wiley. com/doi/full/10.1111/nuf.12269

9. Skela-Savic B, Pesjak K, Hvalic-Touzery S. Low back pain among nurses in Slovenian hospitals: cross-sectional study. Int Nurs Rev. [Internet]. 2017 Apr [cited 2019 Mar 17];64:544-51. Available from: https://onlinelibrary.wiley.com/doi/epdf/10.1111/inr.12376

10. Shoji S, Souza NVDO, Farias SNP. Impacto do ambiente laboratorial no processo saúde doença dos trabalhadores de enfermagem de uma unidade ambulatorial especializada. Rev Min Enferm [Internet]. 2015 [cited 2018 Oct 20];19(1):43-48. Available from: http://www.reme.org.br/sumario/93

11. Pinheiro FA, Tróccoli BT, Carvalho CV. Validação do questionário Nórdico de sintomas osteomusculares como medida de morbidade. Rev Saúde Pública [Internet]. 2002 [cited 2018 Aug 12];36(3):307-12. Available from: http://www.scielo.br/scielo.php?pid=S0034$89102002000300008 \&$ script=sci_abstract\&tIng=pt

12. Mari JJ, Williams P. A validity study of a psychiatric screening questionnaire (SRQ-20) in primary care in the city of Sao Paulo. Br J Psychiatry [Internet]. 1986 [cited 2018 Oct 15];148(1):23-6. Available from: https://www.ncbi.nlm.nih.gov/pubmed/3955316

13. Pinhatti EDG, Ribeiro RP, Soares MH, Martins JT, Lacerda MR. Minor psychiatric disorders in nursing: prevalence and associated factors. Rev. Bras. Enferm. [Internet]. 2018 [cited 2019 Mar 16]; 71(Suppl 5):2176-83. Available from: http://www.scielo.br/scielo.php?script=sci_arttext\&pid=S003471672018001102176\&lng=pt

14. Boughattas W, El Maalel O, Maoua M, Bougmiza I, Kalboussi H, Brahem A, et al. Low back pain among nurses: prevalence, and occupational risk factors. Occup Environ Med. [Internet]. 2017 [cited 2019 Mar 09];5(1):26-37. Available from: https://file.scirp.org/Html/3-1690040_74288.htm

15. Santos EC, Andrade RD, Lopes SGR, Valgas C. Prevalence of musculoskeletal pain in nursing professionals working in orthopedic setting. Rev. Dor [Internet]. 2017 [cited 2019 Mar 08];18(4):298-306. Available from: http://www.scielo.br/scielo.php?script=sci_arttext\&pid=S180600132017000400298\&lng=en

16. Sanjoy, SS, Ahsan GU, Nabi H, Joy ZF, Hossain A. Occupational factors and low back pain: a cross-sectional study of Bangladeshi female nurses. BMC Res Notes [Internet]. 2017 [cited 2019 Mar 09];10(1):173. Available from: https://www.ncbi.nlm.nih.gov/pubmed/28454550

17. Abolfotouh SM, Mahmoud K, Faraj K, Moammer G, EISayed A, Abolfotouh MA. Prevalence, consequences and predictors of low back pain among nurses in a tertiary care setting. Int Orthop [Internet]. 2015 [cited 2019 Mar 10];39(12):2439-49. Available from: https://www.ncbi.nlm.nih. gov/pubmed/26189128

18. Chiwaridzo M, Makotore V, Dambi JM, Munambah N, Mhlanga M. Work-related musculoskeletal disorders among registered general nurses: a case of a large central hospital in Harare, Zimbabwe. BMC Res Notes [Internet] 2018 [cited 2019 Mar 17];11(1):315. Available from: https://www.ncbi. nlm.nih.gov/pubmed/29776452

19. Dlungwane T, Voce A, Knight S. Prevalence and factors associated with low back pain among nurses at a regional hospital in KwaZulu-Natal, South Africa. Heal SA Gesondheid [Internet]. 2018 [cited 2019 Mar 16];23:a1082. Available from: https://www.ajol.info/index.php/hsa/article/ view/182425

20. Sezgin D, Esin MN. Predisposing factors for musculoskeletal symptoms in intensive care unit nurses. Int Nurs Rev [Internet]. 2015 [cited 2018 Oct 25];62(1):92-101. Available from: https:// www.ncbi.nlm.nih.gov/pubmed/25440528 
21. Raithatha AS, Mishra DG. Musculoskeletal disorders and perceived work demands among female nurses at a tertiary care hospital in India. Int J Chronic Dis [Internet]. 2016 [cited 2018 Oct 25]; 2016:5038381. Available from: https://www.hindawi.com/journals/ijcd/2016/5038381/

22. Serranheira F, Sousa-Uva M, Sousa-Uva A. Hospital nurse's tasks and work related musculoskeletal disorders symptoms: A detailed analysis. Work [Internet]. 2015 [cited Mar 08, 2019];51(3):401-9. Available from: https://www.ncbi.nlm.nih.gov/pubmed/25167914

23. Galindo IDS, Ferreira SCM, Lazzari DD, Kempfer SS, Testoni AK. Absenteism reasons in an ambulatorial nursing team. Rev Enferm UFPE [Internet]. 2017 [cited 2019 Mar 18];11(Suppl 8):3198-3205. Available from: https://periodicos.ufpe.br/revistas/revistaenfermagem/article/ view/110184/22064

24. Zapata ALF. Trastornos osteomusculares en auxiliares de enfermería en la unidad de cuidados intensivos. Cienc Trab [Internet]. 2015 [cited 2019 Mar 16];17(53):150-53. Available from: https:// scielo.conicyt.cl/scielo.php?script=sci_arttext\&pid=S0718-24492015000200009

25. Mantovani VM, Nazareth JK, Maciel DNP, Biasibetti C, Lucena AF, Echer IC. Research absenteeism due to illness among nursing professionals. Rev Min Enferm [Internet]. 2015 [cited 2019 Mar 17];19(3):641-46. Available from: http://www.revenf.bvs.br/scielo.php?script=sci_ arttext\&pid=S1415-27622015000300009\&Ing=pt

26. Portela NLC, Ribamar JR. Work-related musculoskeletal disorders (MSD) and their association with working conditions of nursing. Rev Enferm UFPI [Internet]. 2015 [cited 2019 Mar 15];4(4):8287. Available from: http://www.ojs.ufpi.br/index.php/reufpi/article/view/2754

27. Iguti AM, Bastos TF, Barros MBA. Dor nas costas em população adulta: estudo de base populacional em Campinas. Cad Saúde Pública [Internet]. 2015 [cited 2018 Aug 12];31(12):2546-58. Available from:http://www.scielo.br/pdf/csp/v31n12/0102-311X-csp-31-12-2546.pdf

28. Janzen $\mathrm{K}$, Peters-Watral B. Treating co-occurring chronic low back pain \& generalized anxiety disorder. Nurse Pract [Internet]. 2016 [cited 2018 Oct 22];41(1):12-18. Available from: https:// nursing.ceconnection.com/ovidfiles/00006205-201601000-00003.pdf

29. Silva TPDi, Araújo WN, Stival MM, Toledo AM, Burke TN, Carregaro RL. Musculoskeletal discomfort, work ability and fatigue in nursing professionals working in a hospital environment. Rev Esc Enferm USP [Internet]. 2018 [cited 2019 Mar 17];52:e03332. Available from: http://www. scielo.br/scielo.php?script=sci_arttext\&pid=S0080-62342018000100420\&lng=

30. Santos JNMO, De La Longuiniere ACF, Vieira SNS, Amaral APS, Sanches GJC, Vilela ABA Occupational stress: the exposure of an emergency unit nursing team. Rev Fund Care Online [Internet]. 2019 [cited 2019 Mar 19];11(Spe):455-63. Available from: http://www.seer.unirio.br/ index.php/cuidadofundamental/article/view/6386/pdf

31. Andolhe R, Barbosa RL, Oliveira EM, Costa AL, Padilha KG. Stress, coping and burnout among intensive care unit nursing staff: associated factor. Rev Esc Enferm USP [Internet]. 2015 [cited $2018 \mathrm{Jul}$ 26];49(Spe):58-64. Available from: http://www.scielo.br/scielo.php?script=sci_ arttext\&pid=S0080-62342015000700058

32. González ML, Vives JF. Estrés psicológico y problemática musculoesquelética. Revisión sistemática. Enferm Glob [Internet]. 2015 [cited 2018 Aug 18];14(2):276-300. Available from: http://scielo.isciii.es/scielo.php?script=sci_arttext\&pid=S1695-61412015000200015

33. Santos JKV, Gomes Junior VFF, Souza AS, Farias NS, Marques SS, Costa JM. Socio-demographic and physical-functional profile of low back pain patients assisted in Manaus-AM. Rev Dor [Internet]. 2015 [cited 2018 Aug 18];16(4):272-5. Available from: http://www.scielo.br/scielo. php?script=sci_arttext\&pid=S1806-00132015000400272

34. Bonzini M, Bertu'L, Veronesi G, Conti M, Coggon D, Ferrario MM. Is muskuloeskeletal pain a consequence or a cause of occupational stress? A longitudinal study. Int Arch Occup Environ Health [Internet]. 2015 [cited 2018 Oct 25];88(5):607-12. Available from: https://www.ncbi.nlm. nih.gov/pubmed/25261316 
35. Silva JP, Jesus-Moraleida FR, Felício DC, Queiroz BZ, Ferreira ML, Pereira LM. Fatores biopsicossociais associados com a incapacidade em idosos com dor lombar aguda: Estudo BACE-Brasil. Cien Saude Colet [Internet]. 2017 [cited 2018 Jul 12];24(7):2679-90. Available from: http://www.cienciaesaudecoletiva.com.br/artigos/fatores-biopsicossociais-associados-coma-incapacidade-em-idosos-com-dor-lombar-aguda-estudo-bacebrasil/16494

36. Martinez MC, Latorre MDRDO, Fischer FM. Stressors influence work ability in different age groups of nursing professionals: 2-year follow-up. Cienc Saude Colet [Internet]. 2017 [cited 2018 Jan 23];22(5);1589-600. Available from: http://www.scielo.br/scielo.php?pid=S1413$81232017002501589 \&$ script=sci_arttext\&tIng=en

37. Magnago TSBS, Prochnow A, Urbanetto JS, Greco PBT, Beltrame M, Luz EMF. Relationship between work ability in nursing and minor psychological disorders. Texto Contexto Enferm [Internet]. 2015 [cited 2019 Mar 18];24(2):362-70. Available from: https://doi.org/10.1590/010407072015002580013

38. Carvalho DB, Araújo TM, Bernardes KO. Transtornos mentais comuns em trabalhadores da Atenção Básica à Saúde. Rev Bras Saúde Ocup [Internet]. 2016 [cited 2018 Jan 18];41:e17. Available from: http://www.scielo.br/pdf/rbso/v41/2317-6369-rbso-41-e17.pdf

39. Marconato CS, Magnago ACS, Magnago TSBS, Dalmolin GL, Andolhe R, Tavares JP. Prevalence and factors associated with minor psychiatric disorders in hospital housekeeping workers. Rev Esc Enferm USP [Internet]. 2017 [cited 2018 Aug 16];51:e03239. Available from: http://www. scielo.br/scielo.php?script=sci_arttext\&pid=S0080-62342017000100431

40. Guirado GMP, Pereira NMP. Uso do Self-Reporting Questionnaire (SRQ-20) para determinação dos sintomas físicos e psicoemocionais em funcionários de uma indústria metalúrgica do Vale do Paraíba/SP. Cad Saúde Colet [Internet]. 2016 [cited 2018 Aug 15];24(1):92-98. Available from: http://www.scielo.br/pdf/cadsc/v24n1/1414-462X-cadsc-24-1-92.pdf

41. Silva JLL; Moreno RF; Soares RS, Almeida JA, Daher DV, Teixeira ER. Common mental disorders prevalence among maritime workers of Rio de Janeiro. Rev Fund Care Online [Internet]. 2017 [cited 2018 Aug 16];9(3):676-81. Available from: http://seer.unirio.br/index.php/cuidadofundamental/ article/view/5521/pdf 
NOTE

\section{ORIGIN OF THE ARTICLE}

Extracted from the dissertation - The Nursing work process and its influence on nonspecific low back pain", presented to the Graduate Program in Nursing of the Universidade Federal de Santa Catarina, in 2018.

\section{CONTRIBUTION OF AUTHORITY}

Study design: Cargnin ZA, Schneider DG, Schneider IJC.

Data collection: Cargnin ZA.

Data analysis and interpretation: Cargnin ZA, Schneider DG, Schneider IJC.

Discussion of the results: Cargnin ZA, Schneider DG, Schneider IJC.

Writing and/or critical review of content: Cargnin ZA, Schneider DG, Schneider IJC.

Review and final approval of the final version: Cargnin ZA, Schneider DG, Schneider IJC.

\section{ACKNOWLEDGMENT}

To the Graduate Nursing Program - PEN / UFSC, for all the theoretical basis, quality of teaching and academic support.

\section{APPROVAL OF ETHICS COMMITTEE IN RESEARCH}

Approved in the Research Ethics Committee of the Universidade Federal de Santa Catarina., opinion No.2,081,192/2017 and CAAE: 64164717.1.0000.0121; and Opinion No.1,765,311/2016 and CAAE: 59590916.6.0000.5360.

\section{CONFLICT OF INTEREST}

There is no conflict of interests.

\section{HISTORICAL}

Received: October 25, 2018.

Approved: April 17, 2019.

\section{CORRESPONDING AUTHOR}

Zulamar Aguiar Cargnin

zulamar.aguiar@gmail.com 